\title{
Optimal Cropping Pattern For Dhanshiri Basin For Food Sustainability
}

\author{
Jahanur Rahman, Bibhash Sarma
}

\begin{abstract}
The Dhanshiri basin is a south bank sub-basin of Brahmaputra basin. Major crop seasons are Kharif and Rabi having cropping intensity $90 \%$ and $25 \%$ respectively. The large difference of cropping intensities between the crop seasons results a vast area lying unused during Rabi season. The basin requires yearly production of food crops 508,383 MT against current production of 38,553 MT. This is due to disproportionate crop area distribution and as a result the basin has been suffering from food crisis for a long time. The basin can be food sustainable only by changing cropping pattern with limited land and water resources. Linear Programming (LP) model for maximization of economic benefit is used to suggest an optimal cropping pattern supported by ground water irrigation system, which satisfies the rice, protein and calorie requirements up to the year 2050; protects farmers' affinity towards certain crops and market limitations of certain crops. The ground water availability for irrigation purpose is assessed and fed to the model as input. Different cases are considered for the model to arrive at a logical decision.
\end{abstract}

Index Terms - Cropping, Cropping Pattern, Linear Programming (LP); LINGO. Water Balance.

\section{INTRODUCTION}

Cropping pattern is a dynamic concept which refers the allocation of area among the crops to be cultivated in a basin or area. It is not sure that the present cropping pattern will serve well in future. The cropping pattern of a basin is influenced by the factors such as food habit, socio-economic condition, availability of water, etc. (Hussain M. 2013). The Dhansiri basin (Assam, India) has all resources for cultivation throughout the year but still the basin has been food deficit. This is due to unused large agricultural areas during Rabi season and needs proper irrigation planning (K.K. Das, B. Sarma, 2018) for more productivity. This study is an attempt to make the basin food surplus by designing an optimal cropping pattern (Srinivasa Raju et.al. 2000). The other requirements are water availability, minimum required protein and calorie production, protecting farmers crop affinity and maximum marketing capacities of different crops. Linear programming (L P) model (Hasan Symum and Mohammad F Ahmed, 2015) with an objective function to maximize net benefit is solved by using LINGO software. The constraints for the model are Land and water availability of the basin and requirements are food, protein and calorie as per FAO. Water balance (Rajagoud G. and Omkar A.C., 2016)

Jahanur Rahman, Research Scholar, Assam Engineering College, Jalukbari, Guwahati-Assam

Bibhash Sarma, Associate Professor, Civil Engineering, Assam Engineering College, Guwahati-Assam study is carried out to know availability of surplus water for agricultural purpose and after all outgoings the surplus water should be more than the sum of the crop water requirements (Nitya K B and Shivapur A. V. 2016) by all crops under consideration based on existing cropping pattern. The basin has ground water potential of $1316.44 \mathrm{mcm}$ (North Eastern Region Ministry of Water Resources Guwahati August 2013) and stage of development is only $17 \%$. Water requirements among different for the basin are estimated for water balance and surplus water for agricultural purpose in the basin is found to be $583.50 \mathrm{mcm}$. This net available balance water can be used in linear programming as water availability constraint. CROPWAT and CLIMWAT are used to calculate crop water requirements. Several plans are proposed for the model and ultimately a decision is taken on optimal cropping pattern from the solutions of the plans.

\section{AN OVERVIEW OF THE DHANSHIRI BASIN}

The Dhanshiri Basin is the only major important Basin in Golaghat District of Assam. The basin is named after the river Dhanshiri. The Dhanshiri River is a South Bank Tributary of the mighty River Brahmaputra. The Basin lies between Latitudes $26^{\circ} 42^{\prime \prime} \mathrm{N}$ and $25^{\circ} 21^{\prime \prime} \mathrm{N}$ and Longitudes $94^{\circ} 37^{\prime \prime} \mathrm{E}$ and $93^{\circ} 10^{\prime \prime} \mathrm{E}$. The location of the basin in Assam is shown in Fig 1. The area of Dhanshiri basin under Golaghat District is about 3,502 sq. $\mathrm{km}$ or $350,200 \mathrm{ha}$, which is the area under this study. The Basin is situated at about $100.00 \mathrm{~m}$ above the mean sea level in Nagaland and the average altitude of the Basin is $60.60 \mathrm{~m}$. The Basin topography in the study part is slightly undulating and light to dense forest. The natural slope of the basin is from south to north and east to west and the resultant slope is southwest. The reserve forests Nambor, Dayang, Kaliyoni wild life sanctuary, occupy and world famous Kaziranga wild life sanctuary covering total forest area about 286,000 hectares. The basin is named after river Dhanshiri. Major tributaries are Dayang, Diphlu and Gelabil on right bank and Nambor, Doigurung, and Kaliyoni on the left bank of river Dhanshiri and Dhanshiri River is a south bank tributary of the mighty river Brahmaputra.

The basin is very rich in Surface and Ground water potential. The river Dhanshiri is the major source of surface water. There are some other tributaries that joined the river Dhanshiri. Though some minor and major irrigation schemes were constructed taking water from river Dhanshiri, but none of them are running satisfactorily due to so many reasons. The basin is rich in Ground water potential for agricultural development. The existing draft is only $17 \%$. The basin has two major crop seasons Kharif and Rabi. Kharif cropping intensity is more than $90 \%$ but only $25 \%$ for Rabi season. As a result large area of the basin is lying unused during Rabi season and becomes the cause of food crisis for the basin. 


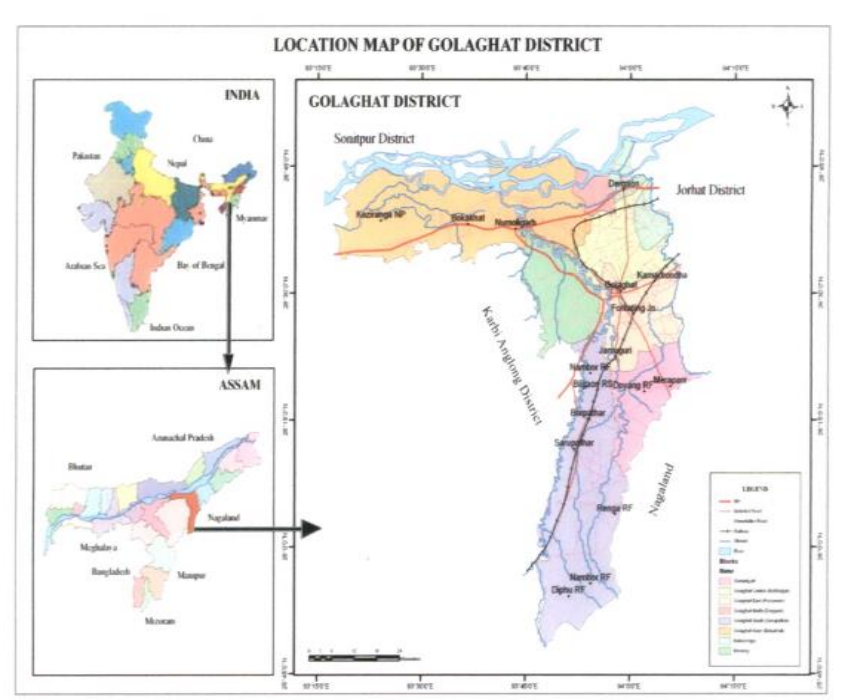

Fig I: Location of Dhanshiri basin in Assam.

\section{WATER BALANCE STUDY}

To propose a new cropping pattern available water potential of basins should be studied thoroughly. Allocation of area for different crops depends on water balance of that area. Water balance study is done on ground water potential since surface water potential of the basin is not dependable for agricultural. As per Central Ground Water Board, Govt. of India report, the ground water potential of the basin is $1316.2 \mathrm{mcm}$ with an annual draft of $221.0 \mathrm{mcm}$. Present ground water withdrawal status is $17 \%$ and up to $70 \%$ it is considered as safe draft. So, further $53 \%$ withdrawal is possible. For water balance study, present and future water requirement for domestic need (human and livestock), industrial needs, recreational, etc. are calculated based on forecasted human and livestock population for the year 2050. Industrial water demand is considered same as total domestic water demand (as per the guideline given by National Water Development Agency,
2016). Total water requirement for all these sectors along with existing draft is $396.32 \mathrm{mcm}$ given in Table - 1. The maximum safe ground water draft for the study area is 921.37 $\mathrm{mcm}$. Balance ground water potential for future agricultural use is $583.50 \mathrm{mcm}$. The summery of water balance report is given in Table -1

Table - 1

Water Balance Report

\begin{tabular}{|c|l|r|}
\hline S1. No. & \multicolumn{1}{|c|}{ Particulars } & \multicolumn{1}{|c|}{$\begin{array}{c}\text { Quantity } \\
(\mathrm{mcm})\end{array}$} \\
\hline 1 & Gross ground water potential & 1316.24 \\
\hline 2 & $\begin{array}{l}\text { For safety maximum 70\% 13116.24 } \\
\text { mcm can be used. }\end{array}$ & 921.37 \\
\hline 3 & Existing draft & 221 \\
\hline \multirow{2}{*}{4} & Domestic water demand & 11 \\
\cline { 2 - 3 } & (a) Urban & 39.54 \\
\cline { 2 - 3 } & (b) Rural & 7.54 \\
\cline { 2 - 3 } & (c) Livestock & 58.44 \\
\cline { 2 - 3 } & (d) Total Domestic Demand & 58.44 \\
\hline 5 & Industrial Water Demand & Nil \\
\hline 6 & Hydro-power demand & 396.32 \\
\hline 6 & Total Water Demand [3 +4 +5+6] & 583.5 \\
\hline 7 & $\begin{array}{l}\text { Balance water for Irrigation } \\
\text { Development [2 -6] }\end{array}$ & \\
\hline
\end{tabular}

\section{EXISTING CROPPING PATTERN}

Cropping pattern is a dynamic concept. It is the allocation of area under different crops for a basin in a particular crop season. It may not be continued permanently, even in next year for the same crop season. Area allocation for different crops depends on profit earned from the crops and their requirements. So for a particular crop season, different crops have to be allocated different area. The existing cropping pattern is given in Table -2

Table - 2

Existing Cropping Pattern with net return

\begin{tabular}{|c|c|c|c|c|c|c|c|c|}
\hline \multirow[t]{2}{*}{ Crop } & \multirow[t]{2}{*}{$\begin{array}{c}\text { Crop } \\
\text { Inde } \\
\mathrm{x} \\
\end{array}$} & \multicolumn{2}{|c|}{$\begin{array}{l}\text { Crop sowing and } \\
\text { harvesting time }\end{array}$} & \multirow[t]{2}{*}{$\begin{array}{l}\text { Area } \\
\text { (ha) }\end{array}$} & \multirow[t]{2}{*}{$\begin{array}{l}\text { Producti } \\
\text { vity } \\
\text { (MT/ha) }\end{array}$} & \multirow[t]{2}{*}{$\begin{array}{c}\text { Rate } \\
\text { (Rs./MT) }\end{array}$} & \multirow[t]{2}{*}{$\begin{array}{l}\text { Overall cost } \\
\text { of } \\
\text { cultivation }\end{array}$} & \multirow[t]{2}{*}{$\begin{array}{l}\text { Net Return } \\
\text { (Rs. In cr.) }\end{array}$} \\
\hline & & From & To & & & & & \\
\hline Kharif paddy (Sali) & K1 & May & Oct & 115038 & 3.1 & 17770 & 51393 & 42.50 \\
\hline Kharif Maize & K2 & June & Oct & 7636 & 2.5 & 17000 & 35460 & 5.38 \\
\hline Kharif Veg. & K3 & June & Oct & 1025 & 5.0 & 10000 & 38250 & 1.20 \\
\hline Rabi Rice (Ahu) & R1 & Dec & Apr & 3570 & 3.0 & 17500 & 50420 & 0.74 \\
\hline Wheat & R2 & Nov & Mar & 243 & 2.5 & 18400 & 35400 & 0.26 \\
\hline Oil seeds & R3 & Nov & Feb & 4956 & 1.0 & 42000 & 31500 & 5.20 \\
\hline Potato & R4 & Nov & Jan & 2213 & 12.0 & 10000 & 104270 & 3.48 \\
\hline Tomato & R5 & Nov & Jan & 1600 & 8.0 & 9000 & 46351 & 4.10 \\
\hline Millet & R6 & Nov & Feb & 1950 & 2.1 & 19500 & 32250 & 1.70 \\
\hline Pulse (all) & R7 & Nov & Jan & 5832 & 1.2 & 44750 & 40150 & 7.90 \\
\hline R. Veg. & R8 & Nov & Jan & 5200 & 5.0 & 10000 & 40150 & 5.12 \\
\hline Summer paddy & S1 & $\mathrm{Feb}$ & May & 4190 & 3.2 & 17250 & 52420 & 1.16 \\
\hline Summer Vegetables & S2 & Feb & May & 850 & 5.0 & 10000 & 38150 & 1.01 \\
\hline Sugarcanes & P1 & Mar & Feb & 5172 & 40.0 & 2750 & 97016 & 6.72 \\
\hline \multirow[t]{2}{*}{ Banana1 } & P2 & Oct & Sep & 2028 & 15.0 & 20000 & 101104 & 40.34 \\
\hline & \multicolumn{7}{|c|}{ Gross net return on existing cropping pattern } & 126.81 \\
\hline
\end{tabular}

Source: Assam Scale of Finance 2016-1 
As per existing cropping pattern of the Dhanshiri Basin it is seen that there are four crop seasons such as Kharif, Rabi, summer and perennial. The major crops of the basin as per present cropping pattern are paddy, maize, wheat, oilseeds, pulses, vegetables, sugarcane and banana. From the pattern it is seen that demand for paddy cultivation is given highest priority since the principal food for the basin is rice. The present paddy production capacity of the basin is $343,835 \mathrm{MT}$ but still it is not enough to meet the food demand for the basin. Existing land use and land cover of the basin is shown in Figure 2.

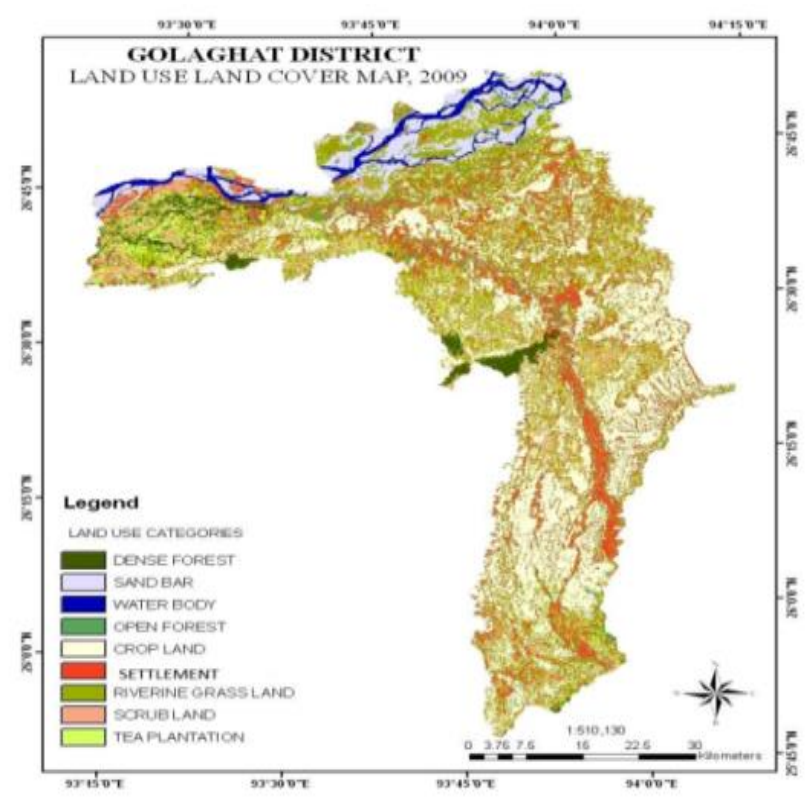

Fig 2: Existing Land use pattern of the basin

\section{PROPOSED CROPPING PATTERN}

Cropping pattern is a dynamic concept and may not be continued in future. When a cropping pattern fails to meet some most important requirement it needs to be changed. The Dhanshiri basin area is very fertile with all resources but due to lack of proper use of all these resources the Dhanshiri basin has been running as food deficit. The main cause for food crisis is disproportionate of area distribution for different crops in different seasons. The basin has very high potential which are required for agricultural development such as manpower, land and available water for irrigation. This study is an attempt to make the basin food sustainable till 2050 by changing existing cropping pattern. The present population growth rate of India based on census report 2001 and 2011 is $12.5 \%$. Considering this growth rate as an average rate the forecasted population for the Dhanshiri basin will be $17,03,622$ and yearly paddy requirement for the basin is 508,383 MT (as per FAO recommendation) against yearly production $343,835 \mathrm{MT}$ and additional 165,584 MT is required to be produced. FAO also recommended minimum protein and calorie requirements to maintain good health of the people. Keeping in view all these facts an optimal cropping pattern suitable for the basin has to be proposed so that the basin will become a food sustainable up to the year 2050 .

\section{LINEAR PROGRAMMING MODEL FORMULATION}

The best way to propose an optimal cropping pattern is optimization by Linear Programming (LP) model. FAO developed software LINGO is used for solving the LP model. A LP model has an objective function subjected to some constraints. The objective function considered here is the maximization of net benefits from crops. The constraints for this model are water availability constraint, area availability constraint, minimum protein and calorie requirements, farmer's affinity towards some crops (minimum area under some crops) and market limitation (maximum area under some crops). The yield of crops (Y), market rate (R) and cost (C) of cultivation per hector for each crop are collected from current "Scale of Finance", Department of Agriculture, Government of Assam for the financial year 2017-18 and are shown in Table 2. For water availability constraint, total water potential available is taken from the water balance study report. Similarly protein and calorie values for different crops are given by FAO (shown in Table 3). The requirement of rice, protein and calorie as per FAO is $818 \mathrm{gm}, 62 \mathrm{gm}$ and $2200 \mathrm{Kcal}$ per head per day, respectively. The total land available is the cultivable command area.

Table - 3

FAO requirement

\begin{tabular}{|c|c|c|c|c|}
\hline $\begin{array}{l}\text { Sl. } \\
\text { No. }\end{array}$ & $\begin{array}{c}\text { Particula } \\
\text { rs }\end{array}$ & $\begin{array}{c}\text { FAO's Per } \\
\text { Capita } \\
\text { Recommendati } \\
\text { on. }\end{array}$ & $\begin{array}{c}\text { Total } \\
\text { Requirement }\end{array}$ & Remarks \\
\hline 1 & Paddy & $450 \mathrm{gm}$ & $\begin{array}{l}5,09,383 \mathrm{MT} \\
\text { and area } \\
\text { required } \\
1,75,650 \text { ha }\end{array}$ & \multirow{3}{*}{$\begin{array}{l}\text { Projected } \\
\text { population } \\
\text { in } 2050= \\
17,03,622\end{array}$} \\
\hline 2 & Protein & $62 \mathrm{gm}$ & $38,553 \mathrm{MT}$ & \\
\hline 3 & Calorie & $2200 \mathrm{kcal}$ & $\begin{array}{l}1.368 \times 10^{12} \\
\text { kcal. }\end{array}$ & \\
\hline
\end{tabular}

The objective function of the LP model is taken as:

$\operatorname{Max} \mathrm{Z}=\sum\left(\mathrm{Y}_{\mathrm{i}}^{\mathrm{j}} \mathrm{x} \mathrm{R}_{\mathrm{i}}^{\mathrm{j}}-\mathrm{C}_{\mathrm{i}}^{\mathrm{j}}\right) \mathrm{A}_{\mathrm{i}}^{\mathrm{j}}$

Where,

- $\quad \mathrm{Y}_{\mathrm{i}}^{\mathrm{j}}=$ Yield of crop ' $\mathrm{i}$ ' during season ' $\mathrm{j}$ ' in MT/ha.

- $\quad \mathrm{R}_{\mathrm{i}}^{\mathrm{j}}=$ Rate of crop ' $\mathrm{i}$ ' during season ' $\mathrm{j}$ ' Rs/MT.

- $\quad \mathrm{C}_{\mathrm{i}}^{\mathrm{j}}=$ Cost of cultivation of crop ' $\mathrm{i}$ ' during season ' $\mathrm{j}$ ' in $\mathrm{Rs} / \mathrm{ha}$

- $\quad \mathrm{A}_{\mathrm{i}}^{\mathrm{j}}=$ Area of crop ' $\mathrm{i}$ ' during season ' $\mathrm{j}$ ' in Rs/ha.

- $\mathrm{i}=$ Name of crops as per existing practice.

- $\mathrm{j}=$ Crop season like kharif or Rabi or summer or perennial

\section{CONSTRAINTS:}

i. Water availability constraint (WA)

Total water potential of the basin should be more than or equal to the total irrigation requirements for all the crops.

$\sum \mathrm{I}_{\mathrm{i}}^{\mathrm{j}} \times \mathrm{A}_{\mathrm{i}}^{\mathrm{j}} \leq \mathrm{WA}$;

Where,

$\mathrm{I}_{\mathrm{i}}^{\mathrm{j}}=$ Irrigation requirement for crop " $\mathrm{i}$ " during season " $\mathrm{j}$ ".

$A_{i}^{j} \quad=$ Area for crop " $i$ " during season " $j$ ”.

$\mathrm{WA}=$ Available water for irrigation 


\section{ii. Area (A) constraint:}

Total Cultivable Command Area of the Dhanshiri River basin is $1,35,000$ ha which should be greater than or equal to the total area allocated at a time.

$$
\begin{aligned}
& \sum \mathrm{A}_{\mathrm{i}}^{\mathrm{K}+\mathrm{P}} \leq \mathrm{CCA} \\
& \text { Where, } \\
& \mathrm{i}=\mathrm{K} 1 \text { to } \mathrm{K} 3 \& \mathrm{P} 1 \text { to } \mathrm{P} 2 \\
& \text { and } \sum \mathrm{A}^{\mathrm{R}+\mathrm{S}+\mathrm{P}}{ }_{\mathrm{i}} \leq \mathrm{CCA}
\end{aligned}
$$

Where,

$$
\begin{aligned}
& \mathrm{i}=\mathrm{R} 1 \text { to } \mathrm{R} 8, \mathrm{~S} 1 \text { to } \mathrm{S} 2 \& \mathrm{P} 1 \text { to } \mathrm{P} 2 \\
& \mathrm{CCA}=\text { Cultivable Command Area. }
\end{aligned}
$$

\section{iii. FAO constraint on Protein requirement $\left(\operatorname{Pro}_{(\mathbf{R})}\right)$ :}

$$
\sum \mathrm{A}_{\mathrm{i}}^{\mathrm{j}} \mathrm{x} \mathrm{Y}_{\mathrm{i}}^{\mathrm{j}} \operatorname{Pro}_{\mathrm{i}}^{\mathrm{j}} \leq\left(\operatorname{Pro}_{(\mathrm{R})}\right)
$$

Where,

$\mathrm{A}_{\mathrm{i}}^{\mathrm{j}}=$ Area for crop "i" during season " $\mathrm{j}$ ".

$\mathrm{Y}_{\mathrm{i}}^{\mathrm{j}}=$ Yield of crop ' $\mathrm{i}$ ' during season ' $\mathrm{j}$ ' in MT/ha.

Pro $_{i}^{j}=$ Protein content for crop " $i$ " during season “ $j$ " in $\mathrm{kg} / \mathrm{MT}$ ).

$\mathrm{Pro}_{(\mathrm{R})}=$ Total protein requirement in MT.

\section{iv. FAO constraint on Calorie requirement $\left(\mathrm{Cal}_{(\mathbf{R})}\right)$ :}

$\sum \mathrm{A}_{\mathrm{i}}^{\mathrm{j}} \mathrm{X} \mathrm{Y}_{\mathrm{i}}^{\mathrm{j}} \mathrm{Cal}_{\mathrm{i} \geq}^{\mathrm{j}}\left(\mathrm{Cal}_{(\mathrm{R})}\right)$;

Where,

$\mathrm{A}_{\mathrm{i}}^{\mathrm{j}}=$ Area for crop "i $\mathrm{i}$ " during season " $\mathrm{j}$ ".

$\mathrm{Y}_{\mathrm{i}}^{\mathrm{j}}=$ Yield of crop ' $\mathrm{i}$ ' during season ' $\mathrm{j}$ ' in MT/ha.

$\mathrm{Cal}_{\mathrm{i}}^{\mathrm{j}}=$ Calorie content for crop " $\mathrm{i}$ ” during season " $\mathrm{j}$ "

in $\mathrm{kcal} / \mathrm{MT})$.

$\mathrm{Cal}_{(\mathrm{R})}=$ Total calorie requirement in kcal.

\section{v. FAO constraint on Paddy requirement $\left(\operatorname{Paddy}_{(\mathrm{R})}\right)$ :}

It is estimated that $40 \mathrm{MT}$ of gross paddy gives $25 \mathrm{MT}$ of net rice. As per FAO, total paddy requirement per head per day is $40 / 22 * 0.450 * 365 *$ total population/1000 MT

$\operatorname{Paddy}_{(\mathrm{R})}=40 / 22 * 0.450 * 365 * 170,622 / 1000$

Total paddy production must be greater than or equal to total paddy requirement for food.

Total paddy produced $(\mathrm{TPP})=\sum \mathrm{Y}_{\mathrm{i}}^{\mathrm{j}} \mathrm{x} \mathrm{A}_{\mathrm{i}}^{\mathrm{j}}$

$\mathrm{TPP} \geq 0.450 * 365 * 1703622$;

Where,

\begin{tabular}{|c|c|}
\hline $\begin{array}{l}\text { Sl. } \\
\text { No. }\end{array}$ & Plan and particulars \\
\hline 1 & $\begin{array}{l}\text { Plan }-1: \text { Existing Cropping pattern } \\
\text { considering only water and area constrains. }\end{array}$ \\
\hline 2 & $\begin{array}{l}\text { Plan }-2: \text { Existing Cropping pattern } \\
\text { considering all constraints. }\end{array}$ \\
\hline 3 & $\begin{array}{l}\text { Plan - 3(A): Existing cropping pattern with } \\
\text { maximum cultivable available area and water } \\
\text { constraints. }\end{array}$ \\
\hline 4 & $\begin{array}{l}\text { Plan }-3(B) \text { : Existing cropping pattern with } \\
\text { maximum area, water constraints, calorie, } \\
\text { protein and FAO requirements. }\end{array}$ \\
\hline 5 & $\begin{array}{l}\text { Plan - 4: Proposed plan protecting minimum } \\
\text { area limit for each crops as per existing } \\
\text { cropping pattern with all constraints. }\end{array}$ \\
\hline 6 & $\begin{array}{l}\text { Plan - 5: Plan }-4 \text { with all constraints but area } \\
\text { limitation on certain crops depending on } \\
\text { importance. }\end{array}$ \\
\hline 7 & $\begin{array}{l}\text { Plan }-6 \text { : With } 10 \% \text { more area for each crop on } \\
\text { Plan }-5 \text {. }\end{array}$ \\
\hline 8 & $\begin{array}{l}\text { Plan - 7: With } 20 \% \text { more additional area for } \\
\text { each crop on Plan }-5 \text {. }\end{array}$ \\
\hline 8 & $\begin{array}{l}\text { Plan }-8 \text { : With } 30 \% \text { more additional area for } \\
\text { each crop on Plan }-5 \text {. }\end{array}$ \\
\hline
\end{tabular}

$\sum Y^{j}{ }_{i}=$ Yield of crop “ $i$ ” during season ' $j$ ”.

$\mathrm{A}_{\mathrm{i}}^{\mathrm{j}}=$ Area of crop "i” during season “ $\mathrm{j}$ ”.
VII. SOLUTION OF THE PLANS AND DISCUSSIONS

Different Plans are proposed for L P Model in search of Optimal Cropping Pattern and are given in Table - 4.Table - 4 Different Plans for the L P model

Plan - 1: Existing Cropping pattern without considering, protein, calorie and $\mathrm{FAO}$ requirements.

This plan is based on existing cropping pattern of the basin. Area constraint is the maximum area under each crop season as per the prevailing crop practice. Apart from land and water constraints no other constraints are used in this plan. Global optimal solution of Plan 1 is Rs. $405.61 \mathrm{Cr}$. According the solution of Plan 1 only three crops are considered for cultivation. These are K3 (Kharif vegetables), S1 (summer paddy) and P2 (Banana 1). Cultivating only these three crops is not enough for the people of the study area and will serve no good. Let us try another plan.

Plan - 2: This plan is proposed just to verify plan 1 with FAO constraints just to know the feasibility of the plan. Inspite of unfavourable solution of plan 1 , at least it allocates some crops but the solution of plan 2 shows infeasibility. It means 
that existing cropping pattern with existing cropped area constraint is not feasible.

Plan - 3 (A): Existing cropping pattern with maximum cultivable available area and water constraints.

From the solution of the above two plans it seen that the existing cropping practice of the study area is very poor quality and does not fulfill any requirement, perhaps due to this every year a large quantities of food crops have to be supplied by the Food and Civil Supply Department of Assam. Total cultivable area for the basin is 127,800 ha excluding 7,200 ha for perennial crops. Since total crop area as per existing cropping pattern is too less to contribute all requirements, so plan 3 is proposed where area constraint is allowed as the maximum available area for cropping in the basin and water constraint is as per water balance study. The solution of this plan allocates only three crops viz K3 (Kharif Veg), R5 (Tomato) and P $2=7200$ (Banana 1). Selection of crops for plan 1 and plan 3 are same but allocated areas are different. The maximum benefit for this plan is Rs.621.14 cr. The benefit is much more than other plans but selection of crops is very poor. The crops tomato and banana are perishable and have market limitations.

Plan 3(B): Plan 3 with FAO constraints.

Plan 3(A) is reproposed by adding all constraints such as land, water and FAO. The solution of plan 3(B) shows feasibility but fails to maintain minimum crop area allocation as per existing cropping pattern. The proposed cropping pattern for the basin should be such that at least it should maintain minimum crop areas for all crops as per current crop of practice. The net benefit comes from this plan is less than plan 3(A) with same numbers of crop selection and fulfillment of FAO's requirements. To protect the minimum area as per existing cropping pattern a new plan has to be proposed. The maximum net benefit of this plan is Rs. $437.75 \mathrm{Cr}$.

Plan - 4: Proposed plan protecting minimum area limit for each crops as per existing cropping pattern with all

Constraints:

Particular types of crops are cultivated for a particular basin to serve some specific needs, so no cropping pattern should be implemented or proposed for a basin ignoring current crop under practice. So plan 4 is proposed with area constraint as the minimum area allocated for each crop as per current practice in addition to all other constraints. The global solution of Plan 4 gives net benefit of Rs. 293.94 Cr. It is seen from the solution of the plan that some crops are allocated minimum area; where as some other crops are given more area allocation than actual requirement. On the other hand some crops are allocated just minimum area where as their importance is much more. For example the plan 4 allocates 62,212 ha for R5 (Tomato), which is perishable and can't be sold above certain limits. So, it is felt that upper limits of area are necessary for some crops which have market limitations. This is done in Plan 5.

Plan - 5: Plan - 4 with area limits on certain crops with all constraints:

Considering the ground reality, in Plan 5, the existing areas under different crops are protected by imposing a lower limit such that the solution does do area allocation bellow that limit and at the same time upper limit also applied in some other crops having restriction to produce more crops. In this situation interaction with the local farmers and knowledgeable person is made regarding area restriction. After interaction plan 5 is proposed as discussed above with all constraints. The maximum net benefit comes from the area allocation for this plan is Rs. 203.92 Cr. Since plan 5 gives a solution which satisfies all requirement for which it may be chosen as the proposed cropping pattern for the Dhanshiri basin. In Plan 5 unless any adverse result comes from plan 6, plan 7 and plan 8 .

\section{Plan 6, $7 \& 8$}

Since plan 5 gives a solution which satisfies all requirement for which optimal cropping pattern is searched. In Plan 5, the existing areas under different crops are protected by imposing a lower limit of areas under crops. The existing cropping pattern is without the irrigation support. Now it is felt necessary to know what happens if we increase the protection level of existing cropping practice. With this concept plan 5 is re-proposed with plan 6 , plan 7 and plan 8 by increasing minimum allocated area by $10 \%, 20 \%$ and $30 \%$ respectively. Though Plan 5 gives the optimal result, these Plans are tested to know the changing future situations considering farmers belief in the current cropping pattern. None of the solutions of these plans give negative benefit. The maximum benefit from plan 5, plan 6, plan 7 and plan 8 are Rs. 203.91 cr, Rs. 188.74 cr, Rs. 176.49 and Rs. 164.06 cr respectively after satisfying all the requirements.

Plane wise net benefit from all plans is shown in fig -3 .

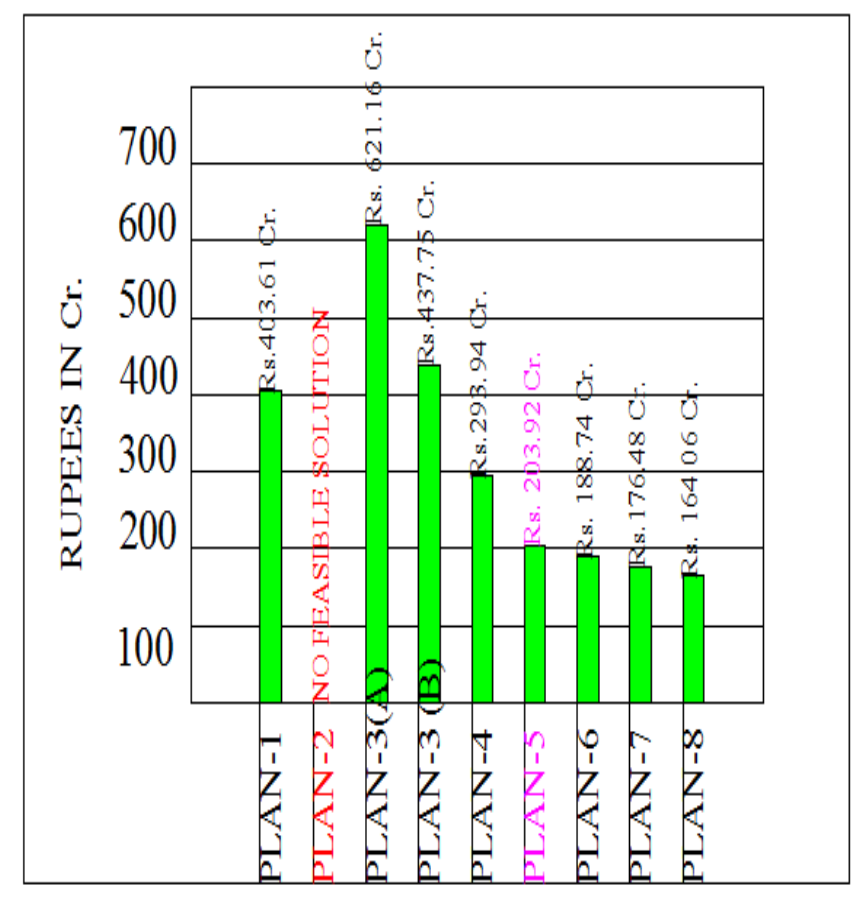

Fig. III: Plan wise maximum net benefit

Plan 5 gives the maximum net benefit considering all constraints. Therefore cropping pattern suggested by Plan -5 is recommended and is shown in Table -5 and outcome of the proposed plan is in Table -6 . 
Table No. 5

Proposed Cropping Pattern with net return

\begin{tabular}{|c|c|c|c|c|c|c|c|c|}
\hline \multirow[t]{2}{*}{ Crop } & \multirow[t]{2}{*}{$\begin{array}{l}\text { Crop } \\
\text { Index }\end{array}$} & \multicolumn{2}{|c|}{$\begin{array}{l}\text { Crop sowing } \\
\text { and } \\
\text { harvesting } \\
\text { time }\end{array}$} & \multirow{2}{*}{$\begin{array}{c}\begin{array}{c}\text { Propose } \\
\text { d Area }\end{array} \\
\text { (ha) }\end{array}$} & \multirow[t]{2}{*}{$\begin{array}{l}\text { Productivity } \\
\text { (MT/ha) }\end{array}$} & \multirow[t]{2}{*}{$\begin{array}{c}\text { Rate } \\
\text { (Rs./MT) }\end{array}$} & \multirow[t]{2}{*}{$\begin{array}{c}\text { Overall } \\
\text { cost of } \\
\text { cultivation }\end{array}$} & \multirow[t]{2}{*}{$\begin{array}{l}\text { Net Return } \\
\text { (Rs. In cr.) }\end{array}$} \\
\hline & & From & To & & & & & \\
\hline $\begin{array}{l}\text { Kharif } \\
\text { paddy } \\
\text { (Sali) }\end{array}$ & $\mathrm{K} 1$ & May & Oct & 115038 & 3.1 & 17770 & 51393 & 42.50 \\
\hline $\begin{array}{l}\text { Kharif } \\
\text { Maize }\end{array}$ & $\mathrm{K} 2$ & June & Oct & 7636 & 2.5 & 17000 & 35460 & 5.38 \\
\hline $\begin{array}{l}\text { Kharif } \\
\text { Veg. }\end{array}$ & K3 & June & Oct & 5126 & 5.0 & 10000 & 38250 & 6.02 \\
\hline $\begin{array}{l}\text { Rabi Rice } \\
\text { (Ahu) }\end{array}$ & $\mathrm{R} 1$ & Dec & Apr & 27,780 & 3.0 & 17500 & 50420 & 5.78 \\
\hline Wheat & $\mathrm{R} 2$ & Nov & Mar & 8540 & 2.5 & 18400 & 35400 & 9.05 \\
\hline Oil seeds & R3 & Nov & Feb & 10655 & 1.0 & 42000 & 31500 & 11.19 \\
\hline Potato & $\mathrm{R} 4$ & Nov & Jan & 24661 & 12.0 & 10000 & 104270 & 38.79 \\
\hline Tomato & R5 & Nov & Jan & 2500 & 8.0 & 9000 & 46351 & 6.41 \\
\hline Millet & R6 & Nov & Feb & 1,950 & 2.1 & 19500 & 32250 & 1.70 \\
\hline Pulse (all) & R7 & Nov & Jan & 5832 & 1.2 & 44750 & 40150 & 7.90 \\
\hline R. Veg. & $\mathrm{R} 8$ & Nov & Jan & 12200 & 5.0 & 10000 & 40150 & 12.02 \\
\hline $\begin{array}{l}\text { Summer } \\
\text { paddy }\end{array}$ & $\mathrm{S} 1$ & Feb & May & 32,832 & 3.2 & 17250 & 52420 & 9.13 \\
\hline $\begin{array}{l}\text { Summer } \\
\text { Vegetables }\end{array}$ & $\mathrm{S} 2$ & Feb & May & 850 & 5.0 & 10000 & 38150 & 1.01 \\
\hline Sugarcanes & $\mathrm{P} 1$ & Mar & Feb & 5172 & 40.0 & 2750 & 97016 & 6.72 \\
\hline Banana1 & $\mathrm{P} 2$ & Oct & Sep & 2028 & 15.0 & 20000 & 101104 & 40.34 \\
\hline \multicolumn{8}{|c|}{ Gross net return on proposed cropping pattern } & 203.92 \\
\hline
\end{tabular}

Table No. 6

Outcome of the optimal cropping pattern

\begin{tabular}{|c|c|c|}
\hline Item & Requirement(MT) & $\begin{array}{c}\text { Production } \\
(\mathrm{MT})\end{array}$ \\
\hline Rice (MT) & 508,763 & 531,130 \\
\hline Protein (MT) & 38,553 & 45,858 \\
\hline Calorie (Kcal) & $1.36801 \mathrm{E}+12$ & $1.99311 \mathrm{E}+12$ \\
\hline
\end{tabular}

\section{CONCLUSION}

After careful study of the existing cropping pattern of Dhanshiri River Basin of Assam it is found that the basin is food deficit. An attempt is made to convert the basin into a food sustainable one by proposing an optimal cropping pattern to be supported by ground water irrigation system. Different Plans are considered under a linear programming model to arrive at a logical decision. The model is solved using LINGO software. The results confirm that the basin is food deficit from the point of view of paddy production and fulfilling calorie and protein requirements. The optimal cropping pattern suggested by the model gives an annual benefit of Rs. $203.92 \mathrm{Cr}$ and would fulfill all food requirements up to the year 2050 . It is also found that the linear programming modeling technique is capable of providing optimal solutions for cropping pattern. However, to make these results meaningful, knowledge on ground realities is a must during formatting stage. 


\section{REFERENCES}

[1] Hasan Symum and Mohammad F Ahmed, 2015, "Linear Programming Model to Optimize Water Supply and Cropping Area for Irrigation: A Case Study for Kalihati” Global Journal of Researches in Engineering: G. Industrial Engineering, Volume 15 Issue 2 Version1.0

[2]Hussain M., 2013 "Impact of Socio-Economic Characteristics of Farmers on Access to Agricultural Credit" Sarhad Journal of Agriculture, Volume 29, Issue 3, pp. 469-476, 2013.

[3] Krishna Kamal Das, Dr. Bibhash Sarma, 2018 "Irrigation Planning for Kulsi River Basin for Maximizing Net Benefit" 594 IJREAMV04I0339138, DOI : 10.18231/2454-9150.2018.0387.

[4] National Water Development Agency, 2016 "Guidelines for Preparation of Preliminary Water Balance Reports”, Ministry of Jal Shakti, Govt. of India, New Delhi

[5]Nitya B. K., Sheedhar R., Dr. Shivapur A. V., 2016," Water Requirements of Selected Crops in Kunigal Command Area", I-manager's Journal of Civil Engineering' - (eISSN 2249-0779, pISSN 2231-1068), Volume 5, Issue 2, March-May 2015, pp24-30.

[6]Rajagoud G. and Omkar A.C., 2016 "Water Balance and Cropping Pattern With Reference to Warangal District of Telengana State" International Journal of Recent Scientific Research, vol. 7, Issue 1, pp.8119-8121, January, 2016

[7] Srinivasa Raju K. and Nagesh Kumar D., 2000, "Optimal Cropping Pattern for Sri Ram Sagar Project: A Linear Programming Approach”. Journal of Applied Hydrology, Volume 13, No.1 \& 2, page 56-57, 2000.

[8] Water Resource Department, Ministry of Water Resource, 2013 “Ground Water Information Booklet Golaghat District, Assam" 